\title{
The system of specially protected natural areas of Kuzbass
}

\author{
Olga Zueva ${ }^{1, *}$ \\ ${ }^{1}$ Federal Research Center for Coal and Coal Chemistry SB RAS, Kemerovo, 650065, Russia
}

\begin{abstract}
On the territory of Kuzbass there are 29 specially protected natural areas with a total area of 1.3 thousand hectares. The existing system of protected areas of Kuzbass is a protected area of federal significance (the State Nature Reserve Kuznetskiy Alatau, the National Natural Park Shorskiy, the State Natural Monument Lipovy Ostrov), 22 protected areas of regional and 4 protected areas of municipal importance. The purpose of this study is to analyze the location of specially protected natural areas in terms of the floristic zoning of Kuzbass and the primary analysis of the PA system in Kuzbass.
\end{abstract}

\section{Introduction}

The problems of biodiversity conservation were identified at the UN Conference, which was held in Brazil in 1992. Then the Convention on Biological Diversity was adopted, which formulated the main environmental provisions of the concept of sustainable development. The Convention on Biological Diversity identifies two main areas of conservation of elements of biological diversity: "in situ" - the conservation of species in natural habitats, as well as the maintenance and restoration of viable populations of species in their natural environment and "ex situ" - the conservation of species outside their natural places habitat [1]. The optimal conditions for plant conservation in situ are considered to be the organization of specially protected natural areas (PAs) and the creation of a network of PAs. About 1800 plant species grow on the territory of Kuzbass. An important condition for the stable conservation of plant species and plant communities in the PA system is the observance of the principle of hierarchy, with the filling of all blocks of the system: federal level, regional level and local [2]. Protected areas of regional significance should cover the maximum possible number of floristic areas represented in the region. Thus, the system of PAs retains not only the uniqueness of species, but also maintains the integrity of the phytocenotic environment of the region. This form of biodiversity conservation is considered to be more successful and efficient [3].

In Russia, the federal law "On Specially Protected Natural Areas" establishes the following forms of protected areas: a) state natural reserves, including biosphere reserves; b) national parks; c) natural parks; d) state nature reserves; e) dendrological parks and botanical gardens; f) health-improving areas and resorts. The laws of the constituent entities

\footnotetext{
*Corresponding author: Olgazueva1705@gmail.com
} 
of the Russian Federation may establish other categories of specially protected natural areas of regional and local significance [4].

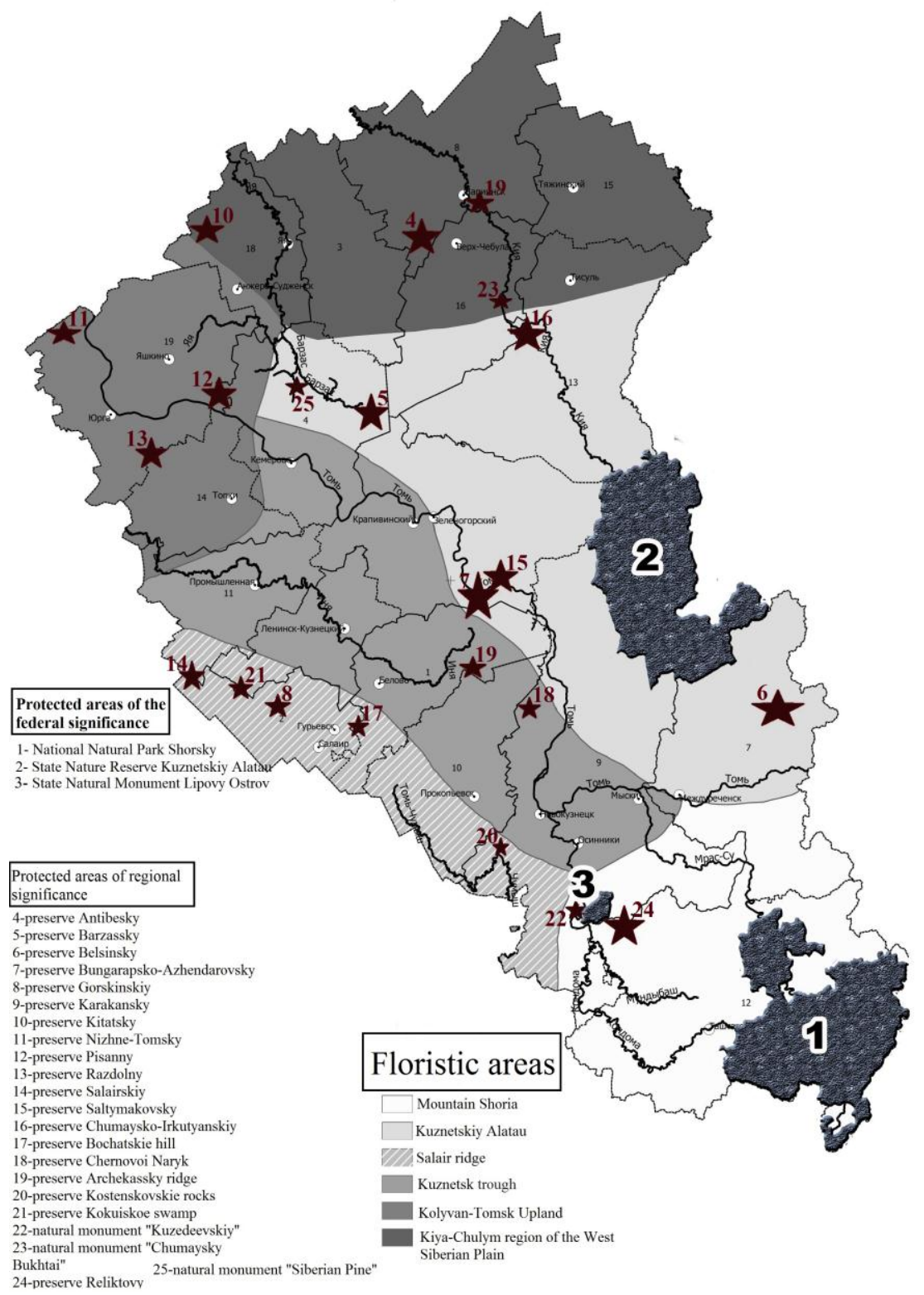

Fig. 1. Distribution of protected areas of Kuzbass by floristic areas

The PA system of Kuzbass consists of 3 levels: federal, regional and local. The protected areas of the federal level include 3 protected areas - the State Nature Reserve Kuznetskiy Alatau, the National Natural Park Shorskiy, and the State Natural Monument Lipovy Ostrov. SPNAs of regional significance include 22 protected areas, PAs of municipal significance consist of 4 protected areas. According to the botanical-geographical and floristic zoning of Kuzbass according to S.A. Sheremetova, 6 working districts are 
allocated on the territory of the region: Mountain Shoria, Kuznetskiy Alatau, Salair ridge, Kuznetsk trough, Kolyvan-Tomsk Upland and Kiya-Chulym region of the West Siberian Plain. [5] The distribution of protected areas in Kuzbass by floristic areas is shown in Fig 1.

In this study, the floristic zoning of Kuzbass was used according to S.A. Sheremetova [5]. Also, previously obtained floristic and geobotanical descriptions of protected areas have been analyzed and used. In addition, the materials stored in the Herbarium of the Kuzbass Botanical Garden were analyzed.

\section{Results and Discussion}

In the initial analysis of the distribution of Kuzbass protected areas by floristic areas, it can be seen that on the territory of the Mountain Shoria floristic region there are 2 protected areas of federal significance, these are National Natural Park Shorsky, the State Natural Monument Lipovy Ostrov and 2 protected areas of the regional level, this is the preserve Reliktovy and the natural monument "Kuzedeevskiy". Within the boundaries of the Kuznetskiy Alatau floristic region, there is 1 protected area of federal significance, these are the Lipovy Ostrov and 6 protected areas of the regional level, these are the reserves "Barzassky", "Belsinsky", "Bungarapsko-Azhendarovsky", "Saltymakovsky", "Chumaysko-Irkutyanskiy" and the natural monument "Siberian Pine". Within the boundaries of the floristic region of the Salair Ridge there are 5 protected areas of the regional level, these are the reserves "Gorskinskiy", "Salairskiy", "Bochatskie hill", "Kokuiskoe swamp" and the natural monument "Kostenskovskie rocks". Within the borders of the Kuznetskaya Kotlovina floristic region there are 3 protected areas of the regional level, these are the reserves "Karakansky", "Chernovoi Naryk" and "BungarapskoAzhendarovsky", as well as 4 natural complexes of the local level, these are "Rudnichny Bor", "Petrovsky", "Petrovsko-Andreevsky" and "Tishinsky". Within the boundaries of the Kolyvan-Tomsk Upland floristic region there are 4 protected areas of the regional level, these are the "Kitatsky", "Nizhne-Tomsky", "Pisanny", "Razdolny" reserves. Within the borders of the floristic region Kiya-Chulymsky region of the West Siberian Plain there are 4 protected areas of the regional level, these are the nature reserves "Kitatsky", "Archekassky ridge", "Antibesky" and the natural monument "Chumaysky Bukhtai". The largest number of protected areas is located in the floristic areas of the Kuznetsk trough and Kuznetsk Alatau. In terms of floristic composition, most plant species are protected in the following territories: reserve "Salairsky" - 682 plant species belonging to 95 families, reserve "Nizhne-Tomsky" - 662 plant species belonging to 92 families and reserve "Bungarapsko-Azhendarovsky" - 565 species belonging to 100 families. During the analysis of the floristic composition in the protected areas, areas were noted where the floristic composition was poorly studied, as well as areas where the floristic inventory took place more than ten years ago. About 800 plant species are protected on the territory of the protected areas of Kuzbass.

\section{Conclusion}

The results obtained show that the protected areas of Kuzbass are located in all floristic regions, which allows preserving in natural habitats the largest number of plant species that grow in different floristic regions of Kuzbass. Thus, in the existing system of protected areas of Kuzbass, not only the uniqueness of the species is preserved, but also the integrity of the phytocenotic environment of the region is maintained. 800 species of plants growing in Kuzbass are preserved on the territory of protected areas, which is $50 \%$ of the total number of species growing in the region. The results also show that the floristic 
composition of some PAs is poorly studied, or the lists of flora are not quite relevant at the moment. In this regard, there is a need for floristic inventories of protected areas in order to more accurately and in detail analyze the system of protected areas in Kuzbass.

\section{References}

1. V.H. Heywood, R.T. Watson, Global biodiversity assessment (1995).

2. The Law of the Kemerovo Region - Kuzbass "On Specially Protected Natural Areas in the Kemerovo Region - Kuzbass" (January 04, 2001, No. 1-O3) (2001).

3. Zueva, O. M., Egorov, A. G. Proceedings of the Tomsk State University, 277, 86-88. (2010).

4. Federal Law "On Specially Protected Natural Areas" dated 03.14.1995 N 33-FZ, (1995).

5. S.A. Sheremetova, Bot. research Siberia and Kazakhstan, 25, 31-41 (2019). 